\title{
Absorption of neutral and basic amino acids across the body surface of two annelid species
}

\author{
D. SIEBERS \\ Biologische Anstalt Helgoland (Zentrale) \\ Hamburg 50, Federal Republic of Germany
}

\begin{abstract}
KURZFASSUNG: Absorption von neutralen und basischen Aminosäuren durch die Körperoberfläche zweier Annelidenarten. In Versuchen zur Aufnahme verschiedener Aminosäuren durch die Körperoberfläche bei dem Oligochaeten Enchytraeus albidus und dem Polychaeten Nereis diversicolor betrug die Absorptionsrate von ${ }^{14} \mathrm{C}-\mathrm{L}$-Arginin aus einer Umgebungskonzentration von $10 \mu \mathrm{M}$ nur wenige Prozent der für Glycin und L-Valin bestimmten Werte. Nach einer halbstündigen Versuchsdauer waren neutrale ${ }^{14} \mathrm{C}$-Aminosäuren im Organismus 9- bis 15 fach gegenüber dem Medium angereichert, die L-Argininverteilung blieb dagegen unterhalb des Aquilibriums. Die konzentrationsabhängige Aufnahmekurve für L-Arginin bestand bei $E$. albidus aus einer Diffusions- und einer Sättigungskomponente, die durch andere Aminosäuren hemmbar war. Die stärkste Inhibition erfolgte durch basische Aminosäuren. Eine erhebliche Hemmung wurde auch durch neutrale Aminosäuren bewirkt. L-Glutamin und L-Asparagin verminderten die L-Argininaufnahme nur geringfügig. Die Gegenwart von sauren, $\beta$ - und $\gamma$-Aminosäuren sowie organischen Säuren und Kohlenhydraten hatte nur einen unbedeutenden oder gar keinen Einfluß zur Folge. Da die L-Argininaufnahme nicht dem Einfluß von Stoffwechselinhibitoren ( $\mathrm{NaCN}$ und Ouabain) unterlag und $\mathrm{Na}^{+}$-unabhängig war, erfüllt die Sättigungskomponente des L-Arginintransports die Merkmale der "erleichterten Diffusion". Der Unterschied zu neutralen Aminosäuren, welche aktiv transportiert werden, wird diskutiert.
\end{abstract}

\section{INTRODUCTION}

A variety of soft-bodied marine invertebrates utilizes an additional food source from uptake of organic matter dissolved in sea water. This mode of nutrition occurs independently of feeding particulate nutrients and digestion in alimentary canals. From a number of experiments conducted in recent years, it can be concluded that absorption of several amino acids and glucose may proceed from extremely low concentrations against considerable concentration gradients of roughly 4 to 6 orders of magnitude, and that absorbed organic matter is accumulated and metabolically utilized (see Stephens, 1972).

Investigations of several marine and brackish water invertebrate species of different phyla have shown that absorption rates of amino acids are positively correlated to ambient salinity levels (Stephens, 1964; Stephens \& Virkar, 1966; SHICK, 1973; Bamford \& Campbell, 1976; Stebers \& Bulnheim, in press), implying that fresh 
water invertebrates cannot obtain significant nutritional profit from uptake of dissolved organic matter. The mechanism which underlies the salinity dependence of amino acid absorption is probably similar to the sodium dependence of solute transport across animal membranes (Schultz \& Curran, 1970).

Results from various cross-inhibition experiments with single animal cells and absorbing tissues, concerning specificities of amino acid absorption suggest separate absorbing systems, which recognize the $\alpha$-amino- $\alpha$-carboxyl configuration of the molecule and its charge. This means that separate uptake systems exist for neutral, basic, and acidic amino acids. While vertebrate cells and gastrointestinal tissues (Wrseman, 1974) and the body surface of intestinal parasites (PAPPAS \& READ, 1975) have been thoroughly investigated in this respect, appropriate information on the mechanisms operating in the body walls of marine invertebrates is - with few exceptions - still lacking. For the body surface of the oligochaete annelid Enchytraeus albidus Sirbers (in press) demonstrated the existence of an uptake system for neutrally charged $\alpha$-amino acids, on which basic amino acids have a small, and acidic amino acids, carbohydrates, and organic acids have no influence.

The present paper is devoted to a more detailed analysis of absorption of neutral and basic amino acids across the body surface in the oligochaete Encbytraeus albidus and the polychaete Nereis diversicolor including the dependence of uptake velocities on energy supply.

\section{MATERIALS AND METHODS}

E. albidus Henle, obtained from earth cultures, was transferred to the bottom filter of all-glass aquaria $\left(15^{\circ} \mathrm{C}, 20 \% \mathrm{~S}\right)$ and used for experiments after about two weeks of submersal life. $N$. diversicolor MüLLER was dug from the surface layer of the bottom of the Sehlendorfer Binnensee, close to the coastline of the western Baltic Sea (Schleswig-Holstein, FRG). Specimens were maintained in a $1 \mathrm{~cm}$ high bottom layer of sand in all-glass aquaria $\left(15^{\circ} \mathrm{C}, 20 \%\right.$, and the water was filtered in circuit. Specimens of 3-4 cm body length were taken for experimental use after about 1 week of acclimation to maintaining conditions. Both species were fed with artificial fish food. (Tetra Min).

Experimental assays were run in a water volume of $10 \mathrm{ml}$, containing about $50 \mathrm{mg}$ of worms (about 15-20 individuals of $E$. albidus and 1 individual $N$. diversicolor), $0.2 \mu \mathrm{Ci}$ of a uniformly labeled ${ }^{14} \mathrm{C}$-amino acid (glycine, L-valine, L-arginine, L-lysine) (Amersham), and 0.1-2.4 $\mu$ moles of unlabeled amino acids of highest purity available.

For experiments concerning effects of metabolic inhibitors on amino acid absorption the incubation medium additionally contained 1-10 $\mu$ moles of ouabain (G-strophantin) $/ 10 \mathrm{ml}$, or $0.5-2.5 \mu$ moles of $\mathrm{NaCN} / 10 \mathrm{ml}$. When effects of sodium depletion were investigated, the incubation media were $20 \%$ sea water, $348 \mathrm{mM} \mathrm{NaCl}$ (the solution corresponds to a salinity of $20 \%$ sea water by aerometry), $87 \mathrm{mM} \mathrm{NaCl}$ + $261 \mathrm{mM} \mathrm{KCl}, 87 \mathrm{mM} \mathrm{NaCl}+261 \mathrm{mM} \mathrm{LiCl}$, and $87 \mathrm{mM} \mathrm{NaCl}+261 \mathrm{mM}$ choline$\mathrm{Cl}$. To realize effects of metabolic inhibitors or sodium-depletion, a preincubation period of $4 \mathrm{~h}\left(15^{\circ} \mathrm{C}\right)$ proved sufficient. 
The experimental time for determination of uptake rates was $0.5 \mathrm{~h}$ throughout all analyses. The salinity of experimental water $(20 \% \mathrm{~S})$ and the temperature $\left(15^{\circ} \mathrm{C}\right)$ were kept constant.

All investigations were run with 4-7 replicates; differences in uptake rates between varying experimental conditions were statistically analyzed by STUDENT's t-test.

For determination of uptake rates the experimental incubation medium was removed, worms were rinsed twice with appropriate incubation medium (not containing inactive or active amino acids), dried on filter paper and stored at $-25^{\circ} \mathrm{C}$. Counting of absorbed label was performed in a Tracerlab liquid scintillation counter with quench correction by internal standard after solubilizing worms for $1 \mathrm{~h}$ at $60^{\circ} \mathrm{C}$ in soluene-350 (Packard) and addition of $10 \mathrm{ml}$ of counting solution $(5 \mathrm{~g} P P O+0.3 \mathrm{~g}$ POPOP/l of toluol).

Before insertion of worms into experimental incubation media, $200 \mu \mathrm{l}$ were removed from $10 \%$ of assays and counted for experimental standard after addition of $200 \mu \mathrm{l}$ of distilled water and $10 \mathrm{ml}$ Insta-Gel (Packard).

The experimental water of $20 \% \mathrm{~S}$ was taken from a 40-1-reservoir, in which it was permanently filtered over gravel at $15^{\circ} \mathrm{C}$ in the dark and only ultra-filtered. Regarding previously used precautionary handling to avoid unknown zero levels of dissolved amino acids (passing a bed of charcoal, shaking with permutite, centrifugation, and ultra-filtration), this handling proved to be unneccessary, since only ultrafiltration of the permanently filtered water revealed identical experimental results. Sea water which is stored in the dark for a long period contains only traces of dissolved amino acids (BoHLING, 1970, 1972), probably due to bacterial degradation.

\section{RESULTS}

\section{Uptake velocities}

Concentration dependent L-arginine uptake velocities in E. albidus are presented in Figure 1. The uptake curve (A) demonstrates a diffusion component, especially at higher substrate concentrations. After subtraction of the diffusion component from uptake curve (A) a saturable component is obtained (B) with a maximum velocity

Table 1

Encbytraeus albidus and Nereis diversicolor. Comparison of absorption capacities from $10 \mu \mathrm{M}$ solutions of glycine, L-valine, and L-arginine $\left(15^{\circ} \mathrm{C}, 20 \% \mathrm{~S}, \mathrm{n}=4\right)$

\begin{tabular}{|ccccc|}
\hline $\begin{array}{c}\text { Absorbed } \\
\text { amino acid }\end{array}$ & $\begin{array}{c}\text { Absorption rate }(\mathrm{n} \text { moles } / \mathrm{g} / \mathrm{h}) \\
\text { Enchytratus } \\
\text { albidus }\end{array}$ & $\begin{array}{c}\text { Nereis } \\
\text { diversicolor }\end{array}$ & $\begin{array}{c}\text { Enchytribution ratio } \\
\text { albidtus }\end{array}$ & $\begin{array}{c}\text { Nereis } \\
\text { diversicolor }\end{array}$ \\
\hline glycine & $211 \pm 20$ & $267 \pm 13$ & 10.6 & 13.4 \\
L-valine & $179 \pm 19$ & $298 \pm 40$ & 8.9 & 14.9 \\
L-arginine & $4.8 \pm 0.2$ & $10.9 \pm 2.7$ & 0.24 & 0.54 \\
\hline
\end{tabular}




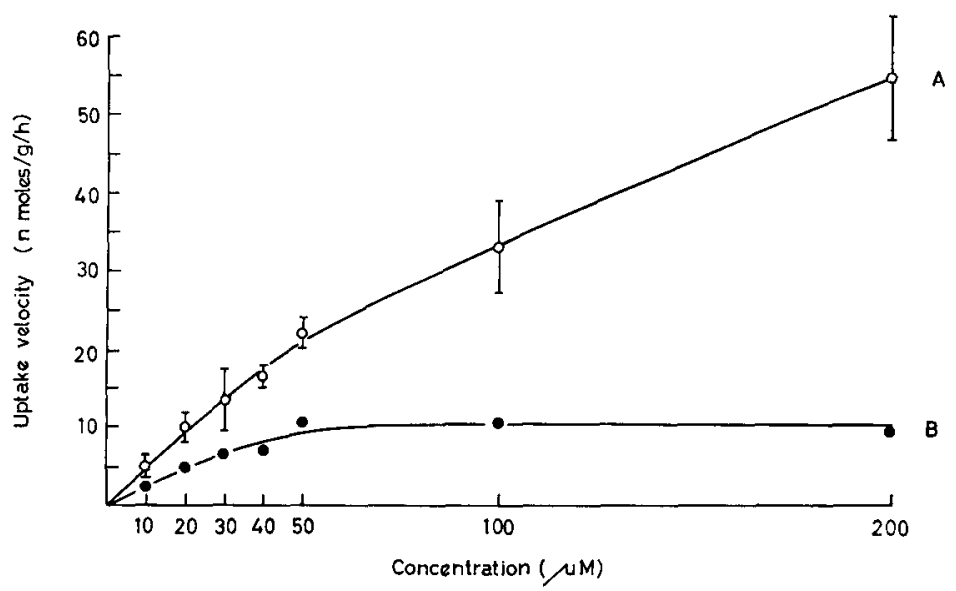

Fig. 1: E. albidus. Concentration-dependent uptake velocity of L-arginine $(A, O)\left(15^{\circ} \mathrm{C}\right.$, $20 \% \mathrm{~S}, \mathrm{n}=4)$. The lower curve $(\mathrm{B},-)$ demonstrates the saturable component after correction for diffusion

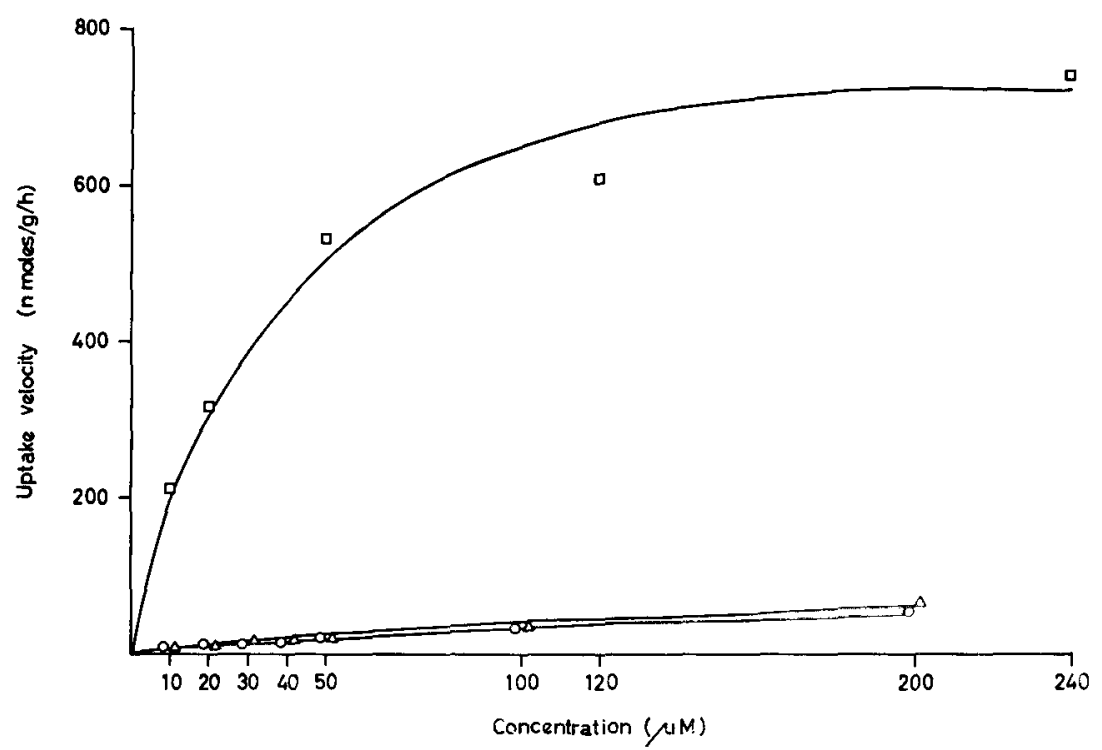

Fig. 2: E. albidus. Comparison of concentration-dependent uptake velocities of glycine ( $\square$ ), L-arginine $(\mathrm{O})$, and L-lysine $(\triangle)\left(15^{\circ} \mathrm{C}, 20 \% \mathrm{~S}, \mathrm{n}=4\right)$

$\left(v_{\max }\right)$ of $10.5 \mathrm{nmoles} / \mathrm{g} / \mathrm{h}$ and a transport constant of $21 \mu \mathrm{M}$ (Lineweaver-Burkplot). Uptake rates of basic amino acids, as exemplified for L-arginine and L-lysine in Figure 2, are much lower than uptake rates of neutral amino acids, as exemplified for glycine. (The uptake curve of L-valine does not differ greatly from that of glycine). At an external concentration of $10 \mu \mathrm{M}\left(15^{\circ} \mathrm{C}, 20 \% \mathrm{~S}\right)$ arginine uptake amounts to only $2.3 \%$ of glycine uptake and $2.7 \%$ of L-valine uptake in E. albidus (Table 1). 
This great difference in uptake rates according to the net charge of the transported amino acid is also valid for the polychaete Nereis diversicolor (Table 1). Uptake of the neutral amino acids glycine and L-valine and positively charged L-arginine was investigated under identical experimental conditions in Enchytraeus and Nereis. In $N$. diversicolor uptake rates are significantly higher by $27 \%$ for glycine, by $66 \%$ for L-valine, and by $127 \%$ for L-arginine than in E. albidus. However, this direct comparison is only partly admissable, because the experimental assays contained about $50 \mathrm{mg}$ of fresh weight; they comprised 15-20 individuals of $E$. albidus and only one individual of $N$.diversicolor which is supplied with a large parapodial body surface area. A much lower uptake rate of $\mathrm{L}$-arginine compared to glycine and $\mathrm{L}$-valine is also found in the polychaete.

The distribution ratios (radioactivity $/ 50 \mathrm{mg}$ of worms : radioactivity/50 $\mu \mathrm{l}$ of ambient water after $0.5 \mathrm{~h}$ of experimental time) range between 8.9 and 14.9 for glycine and L-valine and between 0.24 and 0.54 for L-arginine. They demonstrate a concentrating process for uptake of neutral amino acids. L-arginine distribution ratios, however, do not exceed the equilibrium (distribution ratio $=1$ ) (Table 1 ). Even when assuming an intracellular water amount of roughly $50 \%$ of fresh weight, which contains more than $95 \%$ of total free amino acids - this amino acid distribution seems to be valid for most marine invertebrates (FLORKIN, 1969) - distribution ratios would be roughly doubled, but would not significantly exceed the equilibrium distribution ratio of 1 .

The differences in amino acid absorption between $E$. albidus and $N$. diversicolor are significant (Table 1); however, the values measured are of the same order of magnitude. The oligochaete and the polychaete reveal the same low uptake rates of L-arginine, high distribution ratios of neutral amino acids and small distribution ratios

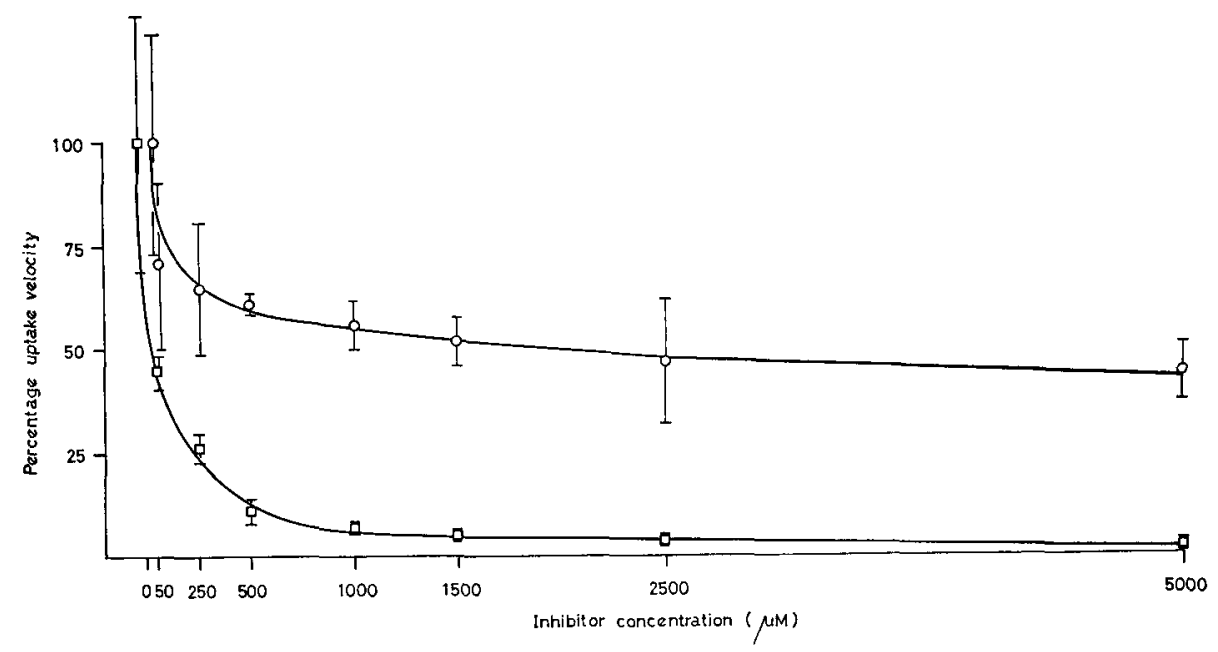

Fig. 3: E. albidus. Inhibition of L-arginine uptake by increasing concentrations of L-alanine (O) and inhibition of glycine uptake by increasing concentrations of L-methionine ( $\square$ ). $\mathrm{L}$-arginine and glycine were absorbed from $50 \mu \mathrm{M}$ solutions in $20 \%$ sea water at $15^{\circ} \mathrm{C}$, $\mathrm{n}=4$ 
of L-arginine, which do not exceed the equilibrium distribution ratio of 1 . This correspondence in absorption data of amino acids indicates that the oligochaete $E$. albidus may be regarded as a possible model organism for transport studies of amino acids and other solutes in annelids.

The existence of a simple diffusion component of L-arginine uptake in E. albidus (Fig. 1) is confirmed by an experiment, in which L-arginine is absorbed from a constant concentration of $50 \mu \mathrm{M}$, with L-alanine concentrations increasing from 0 to $5000 \mu \mathrm{M}$ (Fig. 3). Alanine does not reduce arginine uptake to zero levels. A distinct proportion of $\mathrm{L}$-arginine absorption is not susceptible to inhibition by $\mathrm{L}$-alanine. This proportion is regarded to be the non-saturable simple diffusion component. Glycine absorption, on the contrary, is characterized by saturation kinetics (Fig. 2) without a diffusion component. Increasing concentrations of $\mathrm{L}$-methionine reduce glycine absorption rates to zero levels (Fig. 3). Glycine and L-methionine are regarded to share the same absorptive mechanism for neutral amino acids (SIEBERs, in press).

\section{Specificity of L-arginine transport}

When $\mathrm{L}$-arginine is absorbed by $E$, albidus from $50 \mu \mathrm{M}$ solutions in the presence of $500 \mu \mathrm{M}$ concentrations of different charged and uncharged $\alpha$-amino acids, amino acids amides, $\beta$ - and $\gamma$-amino acids, organic acids, and carbohydrates, arginine transport rates are unchanged in the presence of organic acids and carbohydrates (Fig. 4 ). Arginine uptake is inhibited inconsiderably by acidic amino acids and $\beta$ - and $\gamma$-amino acids. A low, but significant reduction of arginine transport results from the amino acid amides L-glutamine and L-asparagine, while strong reduction of arginine uptake

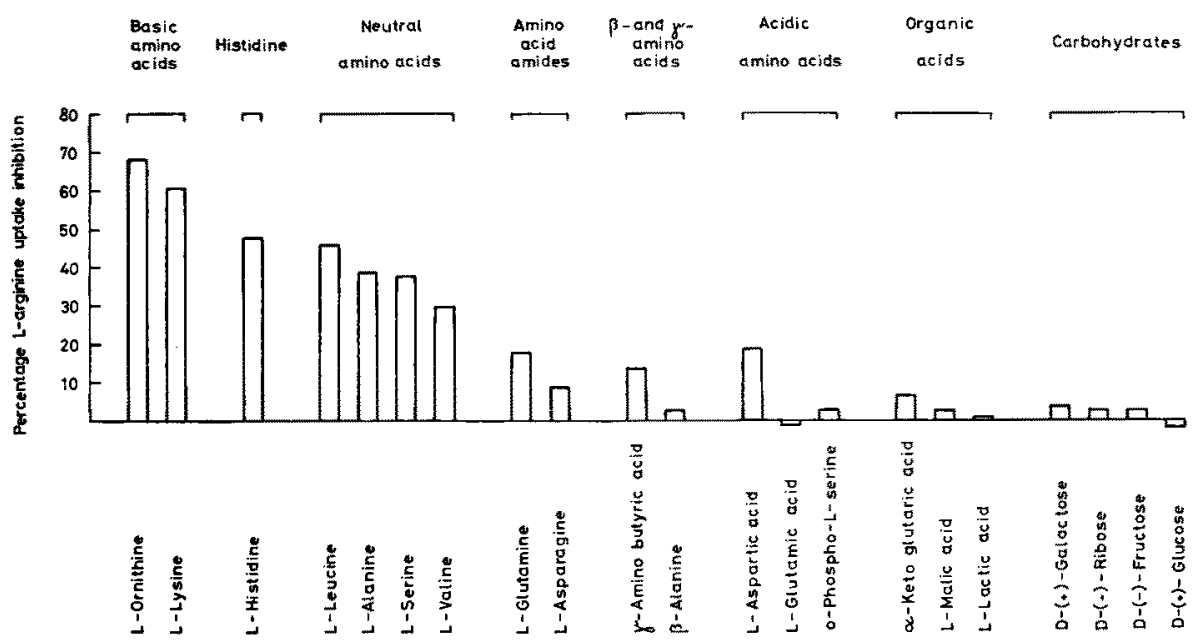

Fig. 4: E. albidus. Inhibition of L-arginine uptake from $50 \mu \mathrm{M}$ solution by $500 \mu \mathrm{M}$ of charged and uncharged $\alpha$-amino acids, amino acid amides, $\beta$ - and $\gamma$-amino acids, organic acids, and carbohydrates $\left(15^{\circ} \mathrm{C}, 20 \% \mathrm{~S}, \mathrm{n}=5\right)$ 
is observed in the presence of the four neutral amino acids tested (L-leucine, L-alanine, $\mathrm{L}$-serine, and L-valine) and L-histidine. The strongest inhibitions result from the dibasic amino acids L-ornithine and L-lysine.

\section{Effect of metabolic inhibitors and Na-depletion}

One of the criteria for the presence of an active transport process is the dependency on energy which is necessary to transport a solute in question against a concentration gradient. A 4-h preincubation of E. albidus in 50,100 and $250 \mu \mathrm{M} \mathrm{NaCN}$, which is known to act as an inhibitor of respiration, proved sufficient to realize significant reductions in uptake rates of neutral amino acids (glycine and L-valine) (Table 2).

Table 2

Enchytraeus albidus. Effect of metabolic inhibitors ( $\mathrm{NaCN}$, Ouabain) on absorption rates of glycine, L-valine, and L-arginine from $10 \mu \mathrm{M}$ solutions after preincubation in appropriate inhibitor concentrations for $4 \mathrm{~h}\left(15^{\circ} \mathrm{C}, 20 \% \mathrm{~S}, \mathrm{n}=7\right)$. " indicates statistical significance of differences in uptake rate $(0.05>\mathrm{p}<0.01)$, indicates high significance $(\mathrm{p}<0.01)$, n.s. indicates no significance $(\mathrm{p}>0.05)$ in comparison to absorption rates in the absence of inhibitors

\begin{tabular}{|c|c|c|c|c|c|c|}
\hline \multirow{2}{*}{$\begin{array}{l}\text { Inhibitor } \\
\text { concentrations }\end{array}$} & \multicolumn{6}{|c|}{ Absorption rates, levels of significance } \\
\hline & Glycine & $(\%)$ & L-valine & $(\%)$ & L-arginine & $(\%)$ \\
\hline no inhibitor & $203 \pm 26$ & $(100)$ & $169 \pm 10$ & $(100)$ & $5.1 \pm 0.4$ & (100) \\
\hline $50 \mu \mathrm{M} \mathrm{NaCN}$ & $138 \pm 18 * *$ & (68) & $103 \pm 3 \%$ & (61) & $4.6 \pm 0.5$ n.s. & (90) \\
\hline $100 \mu \mathrm{M} \mathrm{NaCN}$ & $77 \pm 16 * \%$ & (38) & $71 \pm 7 \cdots$ & $(42)$ & $3.7 \pm 0.7 \%$ & (73) \\
\hline $250 \mu \mathrm{M} \mathrm{NaCN}$ & $45 \pm 14$ & (22) & $29 \pm 5 * 4$ & (17) & $3.5 \pm 0.7 \%$ & (69) \\
\hline $100 \mu \mathrm{M}$ Ouabain & $197 \pm 24$ n.s. & $(97)$ & $110 \pm 8 \%$ & (65) & $5.6 \pm 0.5$ n.s. & (110) \\
\hline $500 \mu \mathrm{M}$ Ouabain & $142 \pm 26^{* *}$ & $(70)$ & $74 \pm 10 *$ & (44) & $4.6 \pm 0.6 \mathrm{nss}$ & (90) \\
\hline $1000 \mu \mathrm{M}$ Ouabain & $85 \pm 20 \%$ & $(42)$ & $74 \pm 7 \cdots$ & (44) & $4.6 \pm 0.7$ n.s. & (90) \\
\hline
\end{tabular}

At a concentration of $250 \mu \mathrm{M} \mathrm{NaCN}$, only $22 \%$ of glycine and $17 \%$ of L-valine were absorbed from $10 \mu \mathrm{M}$ solutions as compared to the controls with no inhibitor present. These results indicate an energy-depending step in the transport of neutral amino acids. Inhibition of glycine and L-valine transport by ouabain (Table 2) demonstrates secondary active transport of neutral amino acids. Ouabain is known as a potent inhibitor of the monovalent cation pump. Inhibition of neutral amino-acid transport by ouabain demonstrates dependency on Na-transport as the energy-supplying step. L-arginine uptake rates, however, are reduced only in a much smaller degree by increasing concentrations of $\mathrm{NaCN}$ and ouabain. It must be argued that these substances may have complex poisonous effects, following the inhibitory actions mentioned above, and finally cause the death of the animals. Considering these aspects it seems likely that, in contrast to neutral amino acids, the absorptive step of L-arginine is energy-independent. 
In all cases, where active transport of an amino acid or a sugar in an animal tissue has been demonstrated, also Na-dependence was found (SAIER \& STILES, 1975). L-arginine uptake in E. albidus, however, does not depend on external $\mathrm{Na}^{+}$(Table 3).

Table 3

Enchytraess albidus. Effect of Na-depletion on uptake rates of L-arginine from $10 \mu \mathrm{M}$ solutions after preincubation in appropriate incubation media for $4 \mathrm{~h}\left(15^{\circ} \mathrm{C}, 20 \mathrm{~m}, \mathrm{n}=5\right)$. n.s. indicates no significance $(p>0.05)$

\begin{tabular}{|ccc|}
\hline $\begin{array}{c}\text { Composition } \\
\text { of incubation } \\
\text { medium }\end{array}$ & $\begin{array}{c}\text { Uptake rate } \pm \text { s.e. } \\
\text { (n moles/g/h), level } \\
\text { of significance }\end{array}$ & Percentage \\
\hline $20 \% 0$ sea water & $5.3 \pm 1.4$ & 100 \\
$348 \mathrm{mM} \mathrm{NaCl}$ & $4.0 \pm 0.3 \mathrm{n.s.}$ & 75 \\
$87 \mathrm{mM} \mathrm{NaCI}$ & $3.6 \pm 1.2 \mathrm{n.s.}$ & 68 \\
$+261 \mathrm{mM} \mathrm{KCl}$ & $4.0 \pm 1.0 \mathrm{n} . \mathrm{m.}$ & 75 \\
$87 \mathrm{mM} \mathrm{NaCl}$ & & 75 \\
\hline & & \\
\hline $261 \mathrm{mM} \mathrm{LiCl}$ & $4.0 \pm 0.5 \mathrm{nM} \mathrm{NaCl}$ & \\
\hline
\end{tabular}

When the oligochaetes were preincubated for $4 \mathrm{~h}$ in media containing $348 \mathrm{mM} \mathrm{NaCl}$ with a salinity equal to $20 \%$ sea-water controls (as measured by aerometry) or $87 \mathrm{mM}$ $(25 \%) \mathrm{NaCl}+261 \mathrm{mM}(75 \%) \mathrm{KCl}(\mathrm{LiCl}$, choline-Cl) - equimolar to $348 \mathrm{mM} \mathrm{NaCl}-$ a reduction of $\mathrm{L}$-arginine absorption form $10 \mu \mathrm{M}$ solution by $25 \%$ became evident for $348 \mathrm{mM} \mathrm{NaCl}$ in comparison to $20 \% 0$ sea-water controls. Besides $\mathrm{Na}^{+}$, there seem to be one or more components in sea water, which are necessary for complete arginine transport. When 75 mole- $\%$ of the $\mathrm{NaCl}$-solution were exchanged against $\mathrm{K}$-, $\mathrm{Li}$,- or choline-Cl, no further reduction of arginine absorption could be realized. This is in contrast to neutral amino acid transport (glycine and L-valine) (SIEBERS \& BULNHEIM, in press), which is regarded to be $\mathrm{Na}$-dependent.

\section{DISCUSSION}

The above mentioned findings concerning differences in transport between neutral and basic amino acids provide sufficient information for several conclusions. Neutral amino acids are regarded to be actively transported against the concentration gradient from the medium across the body surface in E. albidus, as indicated by the following results, which are listed according to LEHNINGER (1974): (a) Strong inhibition of glycine and L-valine uptake by $\mathrm{NaCN}$ demonstrates dependence of the transport step on metabolic energy (Srebers \& BulNherm, in press). (b) Uptake of amino acids is specific for a given substance. This specificity refers to the charge of amino acids and the position of the amino group (SIEBERS, in press) Neutral $\alpha$-amino acids (glycine, 
L-valine) are transported against the gradient in a saturable process, while basic amino acids (L-arginine and L-lysine) are obviously not concentrated in E. albidus and in $N$. diversicolor (Table 1). (c) The specific inward direction of neutral amino acid transport is demonstrated by SIEBERs \& BulnheIM (in press); in E. albidus glycine influx exceeded efflux by several times. (d) The uptake process of neutral amino acids (glycine, L-valine) is susceptible to selective inhibition by ouabain in E. albidus, demonstrating secondary active transport. Furthermore, neutral amino acid uptake in E. albidus depends on external $\mathrm{Na}^{+}$(Siebers \& BulnHerm, in press).

In contrast to neutral amino acids, uptake of basic amino acids (L-arginine, L-lysine) in E. albidus is extremely slow (Fig. 2), amounting to only few percentages of neutral amino acid absorption rates and not reaching equilibrium distribution ratios. For arginine the uptake curve is composed of a linear diffusion component and a non-linear saturable component (Fig 1), which does not seem to be susceptible to metabolic inhibition by $\mathrm{NaCN}$ and ouabain and is therefore regarded to be independent of energy. Furthermore, arginine uptake is unmodified by depletion of ambient $\mathrm{Na}^{+}$. From the above mentioned findings on basic amino acid transport in $E$. albidus the saturable component of the uptake curve is regarded to fulfill the requirements for applying the term "facilitated diffusion", which means the energy-independent equilibration of a solute across a membrane, including saturation kinetics (Figs. 2, 3) and inhibition by molecules structurally analogous to the permeant considered.

For the gill of the common cockle, Cerastoderma edule, Bamford \& McCreA (1975) obtained evidence that L-lysine is absorbed by a saturable system differing from that for neutral amino acid uptake. Lysine uptake is also masked by diffusion at higher concentrations. The intestine of the polychaete Arenicola marina absorbs L-lysine against a concentration gradient (BAMFORD \& STEWART, 1973). L-lysine is absorbed by the mid-gut of the bivalve Mya arenaria at a concentration ratio which differs only slightly from that for L-alanine and L-histidine (STEWART \& BAMFORD, 1976).

For the body surface of the cestode Hymenolepis diminuta basic amino acids have not yet been demonstrated to be actively transported (PAPPAS \& READ, 1975). However, the uptake system for basic amino acids in this cestode is clearly definable, since basic amino acids do not interact with neutral, acidic, or aromatic amino acids during absorption. These results are in contrast to the present findings for $E$. albidus. Also, in larvae of the cestode Taenia crassiceps a transport system is found which is specific for basic amino acids and not inhibited by neutral, dicarboxylic, and aromatic amino acids (Haynes, 1970; Pappas \& Read, 1973).

The arginine uptake system in the adult male trematode Schistosoma mansoni seems to resemble basic amino acid uptake in E. albidus more than that in cestodes, from which it differs considerably. Arginine uptake by $S$. mansoni was inhibited by neutral and basic amino acids, as was the case in methionine uptake (CHAppell 1974; Pappas \& Read, 1975). As mentioned by Pappas \& Read (1975), this is clearly different from cestodes, in which neutral and basic amino acids do not interact.

$\mathrm{Na}^{+}$-independent facilitated diffusion of amino acids was reported by WINTER \& Christensen $(1964,1965)$ for human and rabbit erythrocytes.

In vertebrate intestinal absorptive tissues a discrete transport mechanism for basic 
amino acids exists, which is less efficient than that for neutral amino acids, operating at lower concentrations (WISEMAN, 1974). In sacs of everted small intestine of the rat, for instance, DL-ornithine and L-lysine are actively transported at a $\mathrm{K}_{\mathrm{t}}$-value and a $\mathrm{v}_{\max }$ of only about $10-20 \%$ of neutral amino acid absorption data.

The preceding literature citations and present results do not provide sufficient information for conclusions concerning amino acid transport from a comparative view. On the other hand, the findings on amino-acid absorption in E. albidus confirm present concepts in regard to specificities of transport systems, which refer to the $\alpha$-position of the amino group and the net charge of the amino acid molecule.

\section{SUMMARY}

1. Absorption of L-arginine across the body surface of the oligachacte Enchytraeus albidus and the polychaete Nereis diversicolor from $10 \mu \mathrm{M}$ ambient concentrations proceeds at only few percentages of glycine and L-valine uptake rates. Distribution ratios do not exceed equilibrium. In $E$. albidus L-lysine is transported at the same low rates as observed for $\mathrm{L}$-arginine.

2. In $E$. albidus the concentration dependent uptake of L-arginine consists of a saturable component and a diffusion component. The saturable component is susceptible to inhibition by structurally analogous substances. This inhibition is strongest in the presence of other basic amino acids and is still significant in the presence of neutral amino acids. Slight inhibition of L-arginine absorption is caused by L-glutamine and L-asparagine, while inhibition of arginine is only inconsiderable in the presence of acidic and $\beta$ - and $\gamma$-amino acids. Arginine uptake rates are unchanged by organic acids and carbohydrates.

3. Because of nonsusceptibility of arginine transport to metabolic inhibitors ( $\mathrm{NaCN}$ and ouabain) and $\mathrm{Na}^{+}$-depletion in $E$. albidus, the saturable component of arginine uptake is regarded to fulfill the requirements for applying the term "facilitated diffusion", which is discussed in relation to the active transport of neutral amino acids.

4. The mode of basic amino acid absorption is discussed in comparison to that in other animal species and absorbing tissues.

Acknowledgements. The author is indepted to Miss U. RIEPER and Mr. T. MINDE for skilful technical assistance.

\section{LITERATURE CITED}

BAmFord, D. R. \& STEWARD, M. G., 1973. Absorption of charged amino acids by the intestine of Arenicola marina. Comp. Biochem. Physiol. 46A, 537-547.

- \& CAMpbell, E., 1976. The effect of environmental factors on the absorption of L-phenylalanine by the gill of Mytilus edulis. Comp. Biochem. Physiol. 53A, 295-299.

- \& MCCrEA, R., 1975. Active absorption of neutral and basic amino acids by the gill of the common cockle, Cerastoderma edule. Comp. Biochem. Physiol. 50A, 811-817.

Chappeli, L. H., 1974. Methionine uptake by larval and adult Schistosoma mansoni. Int. J. Parasit. 4, 361-369. 
Florkin, M., 1969. Nitrogen metabolism. In: Chemical zoology. Ed. by M. Florkrn \& B. T. Scheer. Acad. Press, New York, 4, 147-162.

Haynes, W. D. G., 1970. Taenia crassiceps: Uptake of basic and aromatic amino acids and imino acids. Exp. Parasit. 27, 256-264.

Lehininger, A. I., 1974. Bioenergetik. Thieme, Stuttgart, 261 pp.

Pappas, P. W. \& Read, C. P., 1973. Permeability and membrane transport in the larva of Taenia crassiceps. Parasitology 66, 33-42.

- - 1975. Membrane transport in helminth parasites: A review. Exp. Parasit. 37, 469-530.

Saier, M. H., Jr. \& Stiles, C. D., 1975. Molecular dynamics in biological membranes. Springer, New York, 22, 1-129.

Schultz, S. G. \& Curran, P. F., 1970. Coupled transport of sodium and organic solutes. Physiol. Rev. 50, 637-718.

SHICk, J. M., 1973. Effects of salinity and starvation on the uptake and utilization of dissolved glycine by Aurelia aurita polyps. Biol. Bull. mar. biol. Lab., Woods Hole 144, 172-179.

SiEBERs, D. Uptake of neutral amino acids by the oligochaete annelid Enchytraeus albidus. J. comp. Physiol. (In press).

- \& Bulnheim, H.-P. Uptake of dissolved glycine by the enchytraeid annelid Enchytraeus albidus in relation to salinity. J. comp. Physiol. (In press).

STEPHENS, G. C., 1964. Uptake of organic material by aquatic invertebrates. III. Uptake of glycine by bradkish water annelids. Biol. Bull. mar. biol. Lab., Woods Hole 126, 150-162.

- 1972. Amino acid accumulation and assimilation in marine organisms. In: Nitrogen metabolism and the environment. Ed. by J. W. Campberl \& L. Goldstein. Acad. Press, London, $318 \mathrm{pp}$.

- \& VIRKAR, R. A., 1966. Uptake of organic material by aquatic invertebrates. IV. The influence of salinity on the uptake of amino acids by the brittle star, Opbiactis arenosa. Biol. Bull. mar. biol. Lab., Woods Hole 131, 172-185.

STEWART, M. G. \& BAMFORD, D. R., 1976. Absorption of soluble nutrients by the mid-gut of the bivalve Mya arenaria (L.). J. mollusc. Stud. 42, 63-73.

Winter, C. G. \& Christensen, H. N., 1964. Migration of amino acids across the membrane of the human erythrocyte. J. biol. Chem. 239, 872.

- 1965. Contrasts in neutral amino acid transport by rabbit erythrocytes and reticulocytes. J. biol. Chem. 240, 3594-3600.

WISEMAN, G., 1974. Absorption of protein digestion products. In: Biomembranes. Ed. by L. A. Manson. Plenum Press, New York, 4, 363-481.

Author's address: Dr. D. SIEBERS

Biologische Anstalt Helgoland (Zentrale)

Palmaille 9

D-2000 Hamburg 50

Federal Republic of Germany 